\title{
IMPLEMENTASI KUOTA $30 \%$ CALON LEGISLATIF PEREMPUAN DI GRESIK PADA PEMILU TAHUN 2014
}

\author{
Alif Hidayati \\ Tarakan express II. Parang Barong 19 Indrapura Surabaya | leafmyallif@gmail.com
}

\begin{abstract}
This paper addresses the issue of how the implementation of the $30 \%$ quota of the women legislative candidates in the electoral district 4 in Gresik in 2014 general election according to UndangUndang No. 8 tahun $20 / 2$ and the political (siyasah) jurisprudence. The data are collected through interview and a study of the texts related to the problem. They are then analyzed using the political (siyasah) jurisprudence approach and accomplished by inductive framework. The study concludes that the implementation of the 30\% quota of the women legislative candidates in the electoral district 4 in Gresik has been in conformity with UU No. 8 tahun 20/2 and Peraturan KPU No 7 tahun 20/3. It is recorded that the women legislative candidates, in the list of the fixed candidates, are $34.61 \%$ or 36 people of the 104 candidates in the electoral district 4 . However, the final result shows that the $34.61 \%$ of the women legislative candidates have not met the 30\% quota. In fact, there are only 2 people (20\%) of the 10 council members who represent the electoral district 4 in Gresik. In Islam, there is none of the discussion of the application of the $30 \%$ quota of the women legislative representation in parliament. Within the perspective of the political (siyasah) jurisprudence, the 30\% quota of the women's representation in parliament are not contrary to the principles of Islam as long as they have the capacity and capability as a leader. It is because Islam adheres the principle of equal right between men and women as mentioned in chapter al-Taubah, verse 7I.
\end{abstract}

Keywords: The 30\% quota, women's representation, general election, legislative

Abstrak: Tulisan ini membahas tentang implementasi kuota 30\% keterwakilan calon legislatif perempuan di dapil 4 Gresik dalam Pemilu tahun 2014. limplementasi kuota 30\% keterwakilan calon anggota 
legislatif perempuan di dapil 4 Gresik sudah sesuai dengan UU No. 8 tahun 2012 dan Peraturan KPU No 7 tahun 2013. Tercatat calon anggota legislatif dalam DCT (Daftar Calon Tetap) yakni terdapat 34,61\% atau sebanyak 36 orang keterwakilan calon legislatif perempuan dari 104 keseluruhan jumlah calon legislatif di dapil 4. Akan tetapi dalam hasil akhirnya 34,61\% keterwakilan perempuan calon anggota legislatif tidak memenuhi kuota 30\%, bahkan hanya ada 2 orang (20\%) dari 10 orang anggota dewan yang mewakili dapil 4 Kabupaten Gresik. Dalam Islam, tidak ditemui satupun pembahasan mengenai penerapan kuota 30\% keterwakilan perempuan di parlemen. Menurut perspektif fikih siya@sah, keterwakilan 30\% kuota perempuan di parlemen tidak bertentangan dengan prinsip Islam selama perempuan yang duduk di parlemen tersebut mempunyai kapasitas dan kapabilitas sebagai seorang pemimpin, karena Islam menganut prinsip kesetaraan hak antara laki-laki dan perempuan sebagaimana dalam surat at-Taubah ayat 7l.

Kata Kunci: Perempuan, pemilu, legislatif.

\section{Pendahuluan}

Kaum perempuan selalu menjadi objek pembicaraan, terutama pada masa yang berdekatan dengan dilaksanakannya Pemilihan Umum (Pemilu). Pada dasarnya Pemilu memang merupakan salah satu sarana utama untuk menegakkan tatanan politik yang demokratis, sehingga nantinya laki-laki dan perempuan sama-sama memiliki kebebasan dalam menentukan hak pilihnya, yang pada hakekatnya hubungan dan kedudukan antara laki-laki dan perempuan haruslah sama, seimbang dan setara.

Keterlibatan perempuan dalam politik dari waktu ke waktu terus mengalami peningkatan, salah satu indikatornya adalah trend peningkatan keterwakilan perempuan di legislatif, terutama sejak Pemilu tahun 1999 hingga Pemilu tahun 2009. Pada Pemilu tahun 1999 jumlah keterwakilan perempuan adalah 9\%, pada 
Pemilu tahun 2004 (11,8\%), Pemilu tahun 2009 (18\%), ${ }^{1}$ dan Pemilu tahun 2014 diharuskan untuk memenuhi target yakni (30\%).

Peningkatan keterwakilan perempuan dalam politik, terutama dalam Pemilu, tersebut tidak terjadi secara serta merta, namun karena perjuangan yang terus menerus untuk memperjuangkan hak setiap orang untuk mencapai kesamaan hak dan keadilan, salah satunya adalah dengan mewujudkan peraturan perundang-undangan yang memiliki keberpihakan afirmatif (kebijakan yang diambil agar golongan/gender tertentu memperoleh peluang yang sama dengan golongan yang lain di bidang yang sama) terhadap keterwakilan perempuan.

Islam telah memberikan persamaan kepada laki-laki dan perempuan yang pada perkembangan zaman perempuan tanpa sadar dituntut untuk lebih berkiprah khususnya dalam kapasitasnya sebagai anggota masyarakat. Dalam Islam telah dijelaskan bahwa perempuan boleh dan berhak berkecimpung dalam bidang politik yang merupakan area publik seperti dalam Q.S. At-Taubah (9): 71 yang artinya:

"Dan orang-orang yang beriman, lelaki dan perempuan, sebahagian mereka (adalah) menjadi penolong bagi sebahagian yang lain. mereka menyuruh (mengerjakan) yang ma'ruf, mencegah dari yang munkar, mendirikan shalat, menunaikan zakat dan mereka taat pada Allah dan Rasul-Nya. Mereka itu akan diberi rahmat oleh Allah; Sesungguhnya Allah Maha Perkasa lagi Maha Bijaksana." 2

Dalam konteks ketatanegaraan Indonesia, persoalan yang berkaitan dengan upaya keterlibatan perempuan ini masih memerlukan beberapa penelitian yang lebih mendalam. Jika melihat kedudukan perempuan yang diatur di dalam undangundang mengenai ketentuan calon legislator perempuan 30\%, seharusnya dapat lebih meningkatkan jumlah keterwakilan

' Ramlan Surbakti, Didik Suprianto dan Hasyim Asyari, Meningkatkan Keterwakilan Perempuan: Penguatan Kebijakan Afirmasi, (Jakarta: Kemitraan Pembaruan bagi Tata Pemerintah, 2009), I .

2 Departemen Agama RI, Al-Qur'an dan Terjemahnya, (Semarang: Asy-Syifa, 1999), 29I. 
perempuan dalam kursi parlemen. Untuk itu tulisan ini dimaksudkan untuk mengetahui implementasi keterwakilan caleg perempuan dalam Pemilu DPRD Gresik pada tahun 2014 dan bagaimana Fikih Siyasah memandangnya.

\section{Pengertian Pemilihan Umum dalam Islam}

Dalam bahasa Arab, Pemilihan Umum disebut al-intikhabah al'ammah. Intikhabah merupakan jama' muannas salim yang berasal dari kata إنتخ ينتخب yang artinya memilih, ${ }^{3}$ sedangkan menurut istilah adalah dikembalikannya hak memilih kepada umat atau rakyat dalam pemilihan kepada wakilnya yang akan mewakili mereka untuk berbicara atas nama rakyat, menuntut hak-haknya, dan membelanya dari hal-hal yang merugikan mereka.

Dalam sejarahnya, istilah Pemilu dalam Islam memang tidak terlalu dikenal. Pemilu muncul di masa-masa kontemporer ini dimana telah terbentuk negara-bangsa yang banyak bercorak demokrasi bagi negara mayoritas muslim khususnya di Timur Tengah dan Asia Tenggara. Namun, sejak zaman Khalifah yang empat (Abu Bakar, Umar, Usman, Ali) yang oleh Mahomed Ullah disebut sebagai periode Republik, ${ }^{4}$ bibit-bibitnya telah muncul walaupun dalam bentuknya yang sederhana. Ini sebagaimana terlihat dalam proses pengangkatan Sahabat Nabi, Abu Bakar di Tsaqifah Bani Sa'idah sebagai Khalifah pertama melalui pemilihan umum yang pada saat itu berbentuk ijma' atau kesepakatan dari para sahabat.

Dilihat dari bentuknya, Pemilu dapat disejajarkan dengan Baiat yang menurut Ibn Khaldun adalah perjanjian atas dasar kesetiaan. Orang yang berbaiat menerima seseorang yang dibaiat menjadi amir atau pemimpin dalam melaksanakan urusan kaum muslimin. Informasi dari al-Qur'an yang berkaitan dengan baiat ini adalah Surah al-Fath ayat 10 yang artinya sebagai berikut:

\footnotetext{
${ }^{3}$ Muhammad Ibn Manzur, Lisan al-'Arab, Jilid I, (Beirut: Dar Shadir, t.t), 75I.

${ }^{4}$ Mahomed Ullah Ibn S. Jung, The Administration of Justice In Islam: An Introduction to The Muslim Conception of The State, (New Delhi: Kitab Bhavan, 1990), x.
} 
“Bahwasanya orang-orang yang berjanji setia kepada kamu sesungguhnya mereka berjanji setia kepada Allah. Tangan Allah di atas tangan mereka, Maka barangsiapa yang melanggar janjinya niscaya akibat ia melanggar janji itu akan menimpa dirinya sendiri dan barangsiapa menepati janjinya kepada Allah, maka Allah akan memberinya pahala yang besar." 5

Dari konteks yang lebih luas, baiat dapat dipahami sebagai konsep perjanjian yang melibatkan dua kelompok yaitu pemerintah dan masyarakat. Dengan kata lain, Pemilu sebagaimana terjadi dalam situasi modern sekarang merupakan perluasan dari istilah baiat dalam konteks fikih siyasah karena sama-sama merepresentasikan serah terima (pemindahan) kekuasaan dari otoritas publik kepada imam dan sumpah (janji setia) imam untuk menjalankan hukum demi memenuhi harapan publik.

\section{Kepemimpinan Perempuan di Legislatif dalam Islam}

Setelah membentuk partai politik sebagai prasyarat mengikuti Pemilu, hal yang perlu dipikirkan oleh umat Islam adalah menentukan siapa yang akan mewakilinya dalam pemerintahan sebagai representasi suara rakyat. Hal ini merupakan instrumen penting dalam perwakilan atau majelis syura yang akan bermusyawarah membentuk konsensus demi kemashlahatan masyarakat. Dalam membuat konsensus untuk menentukan kebijakan publik tersebut, musyawarah dalam lembaga syura merupakan jalan terbaik untuk berkonsultasi satu dengan yang lain atas nama rakyat. ${ }^{6}$

Dalam kajian Islam, keterlibatan perempuan di bidang politik pada dasarnya tidak dibicarakan secara jelas. Dalam fikih siyasah tidak disinggung perempuan dalam politik baik sebagai objek

\footnotetext{
${ }^{5}$ Departemen Agama RI, Al-Qur'an dan Terjemahnya, 738.

${ }^{6}$ John L. Esposito, Islam and Development: Religion and Sociopolitical Change, (New York: Syracuse University Press, 1980), 4.
} 
maupun subjek. Akan tetapi di dalam Islam terdapat pembahasan mengenai kepemimpinan perempuan di bidang publik.

Dasar hukum yang dijadikan landasan bagi kebolehan perempuan untuk berkiprah di kepemimpinan pubik atau legislatif adalah:

a. Firman Allah SWT yang mengisahkan tentang kepemimpinan Ratu Bilqis dalam Surat an-Naml.

Dalam surat ini diceritakan tentang negara Saba' yang makmur dan kaya di bawah kepemimpinan seorang ratu yang bijaksana yang pada akhirnya beriman kepada Allah SWT. Hal ini menunjukkan bahwa Allah SWT tidak melarang perempuan untuk menjalankan pemerintahan, berkiprah menjadi pemimpin, dan juga mengindikasikan bahwa perempuan mampu menjalankan pemerintahan dengan baik. ${ }^{7}$

b. Firman Allah SWT dalam surat at-Taubah ayat 71 yang artinya:

"Dan orang-orang yang beriman, lelaki dan perempuan, sebahagian mereka (adalah) menjadi penolong bagi sebahagian yang lain, mereka menyuruh (mengerjakan) yang ma'ruf, mencegah dari yang munkar, mendirikan shalat, menunaikan zakat dan mereka taat pada Allah dan Rasul-Nya. Mereka itu akan diberi rahmat oleh Allah; Sesungguhnya Allah Maha Perkasa lagi Maha Bijaksana." 8

Ayat ini secara umum dipahami sebagai gambaran tentang adanya kewajiban melakukan kerjasama antara lakilaki dan perempuan di dalam berbagai bidang kehidupan untuk melaksanakan amar ma'ruf nahy munkar. Pengertian amar ma'ruf mencakup segala segi kebaikan atau perbaikan

${ }^{7}$ Ahmad Fudhali, Perempuan Di Lembaan Suci: Kritik Atas Hadits-hadits Shahih, (Yogyakarta: Pilar Reigia, 2005), 225.

${ }^{8}$ Departemen Agama RI, Al-Qur'an dan Terjemahnya, 266. 
kehidupan, termasuk memberi nasehat atau kritik kepada penguasa. ${ }^{9}$

c. Firman Allah SWT tentang Baiat perempuan dalam surat alMumtahanah ayat 12 yang artinya:

"Hai Nabi, apabila datang kepadamu perempuan-perempuan yang beriman untuk mengadakan janji setia, bahwa mereka tiada akan menyekutukan Allah, tidak akan mencuri, tidak akan berzina, tidak akan membunuh anak-anaknya, tidak akan berbuat dusta yang mereka ada-adakan antara tangan dan kaki mereka dan tidak akan mendurhakaimu dalam urusan yang baik, maka terimalah janji setia mereka dan mohonkanlah ampunan kepada Allah untuk mereka. Sesungguhnya Allah Maha Pengampun lagi Maha Penyayang." 10

Dalam ayat ini dijelaskan bahwa Allah SWT menyeru Rasulullah agar menerima baiat kaum perempuan. Sebagaimana diketahui baiat merupakan salah satu kegiatan politik umat yang dilakukan sebagai wujud partisipasi dan kepeduliannya terhadap situasi politik yang terjadi. ${ }^{11}$

Islam mengangkat derajat manusia dan memberikan kepercayaan yang tinggi untuk menjadi khalifah di bumi tanpa membedakan antara laki-laki dan perempuan, karena setiap manusia secara fungsional dan sosial adalah pemimpin sebagaimana yang termaktub dalam surat al-An'am ayat 165 yang artinya:

"Dan Dialah yang menjadikan kamu sebagai khalifahkhalifah di bumi dan Dia mengangkat (derajat) sebagian kamu atas yang lain, untuk mengujimu atas (karunia) yang diberikan-Nya kepadamu. Sesungguhnya Tuhanmu amat

9 M. Quraisy Shihab, Membumikan Al-Qur'an: Fungsi dan Peran Wahyu dalam Kehidupan Masyarakat, (Bandung: Mizan, 1994), 346.

${ }^{10}$ Departemen Agama RI, Al-Qur'an dan Terjemahnya, 804.

"M. Quraisy Shihab, Membumikan Al-Qur'an, 247. 
cepat siksaan-Nya dan Sesungguhnya dia Maha Pengampun lagi Maha Penyayang." 12

Laki-laki dan perempuan mempunyai fungsi yang sama sebagai khalifah yang akan mempertanggungjawabkan tugastugas kehalifahannya di bumi, sebagaimana mereka harus bertanggung jawab sebagai hamba Tuhan. ${ }^{13}$ Dalam bidang kepemimpinan, kita bertolak pada status manusia sebagai khalifah. Tugas khalifah di muka bumi adalah sebagai pengemban amanat Allah untuk mengolah, memelihara dan mengembangkan bumi. ${ }^{14}$ Inilah tugas pokok manusia, tidak membedakan antara laki-laki dan perempuan.

\section{Keterlibatan Perempuan dalam Perumusan Kebijakan Publik}

Kebijakan publik adalah keputusan-keputusan yang mengikat bagi orang banyak pada tataran strategis atau berifat garis besar yang dibuat oleh pemegang otoritas publik. ${ }^{15}$ Dalam bidang publik, Islam memberikan akses yang luas dan adil bagi perempuan dengan membuka lebar aktifitasnya di berbagai bidang publik seperti, mencari ilmu, mencari nafkah, melakukan transaksi, kegiatan sosial dan bahkan aktifitas politik, sama seperti yang dilakukan oleh kaum laki-laki dengan cara terhormat dan bermartabat. Demikianlah Islam telah memberikan kebebasan yang sangat besar kepada perempuan untuk berkiprah di ruang publik.

Lembaga yang bertugas menentukan kebijakan publik lazimnya disebut lembaga legislatif, di dalamnya terdiri dari perwakilan elemen masyarakat. Dalam Islam lembaga legislatif sering disebut dengan ahl al-halli wa al-'aqd. Walaupun tidak sepenuhnya sama, namun salah satu tugas dan fungsi lembaga ini

\footnotetext{
${ }^{12}$ Departemen Agama RI, Al-Qur'an dan Terjemahnya, 150.

13 Nasaruddin Umar, Argumen Kesetaraan Gender Prespektif al-Qur'an, (Jakarta: Paramadina, 1999), 253.

${ }^{14}$ A. Wahid Zaini dkk, Memposisikan Kodrat, (Bandung: Mizan, 1999), 69.

${ }^{15}$ http://id,wikipedia.org/wiki/Kebijakan_Publik, diakses pada 0 I Juni 2014.
} 
menyerupai lembaga legislatif, yakni melakukan pengawasan terhadap pemerintahan.

Lembaga legislatif di dalam Islam sebenarnya mengalami perubahan dari waktu ke waktu seiring dengan perkembangan dan kebutuhan masyarakat. Pada masa Rasulullah saw. sumber kekuasaan legislatif adalah Allah dan dijabarkan oleh Rasulullah saw. dalam sunnahnya, baik perkataan, perbuatan, maupun pengakuannya terhadap perbuatan sahabat. ${ }^{16}$

Pada masa al-Khulafa' ar-Rasyidin wilayah kekuasaan Islam semakin meluas, dan permasalahan yang dihadapi oleh masyarakat pun semakin kompleks, oleh sebab itu para khalifah tidak hanya merujuk pada al-Qur'an dan Sunnah Nabi untuk memecahkan segala permasalahan yang dihadapi, namun mereka juga bertanya kepada para sahabat senior. Secara formal, perundang-undangan dan kebijakan publik dilakukan oleh khalifah. Sehingga kewenangan legislatif pada masa itu belum terkonsentrasi dalam sebuah lembaga atau dewan perwakilan, tetapi berada di tangan khalifah sendiri dengan dibantu dengan sahabat-saahabat lainnya. ${ }^{17}$

Lembaga legislatif atau ahl al-halli wa al-'aqd ini berikutnya berkembang dengan bermacam bentuk sesuai dengan pemerintahan yang berlaku. Namun ada syarat-syarat umum bagi keanggotaan di dalamnya, al-Mawardi menyatakan syarat-syarat tersebut adalah: Adil dengan segala syarat-syaratnya, berilmu, dan memiliki wawasan dan sikap bijaksana. ${ }^{18}$

Peran publik merupakan peran politis yang penting bagi pemberdayaan dan pembangunan manusia seutuhnya. Sehingga tidak mengherankan jika pada masa nabi ditemukan sejumlah aktivis perempuan yang berkompeten setara dengan kaum laki-

\footnotetext{
${ }^{16}$ Muhammad Iqbal, Figh Siyasah Kontekstualisasi Doktrin Politik Isalam, (Jakarta: Gaya Media Pratama, 200I), 164.

17 Ibid., I64-165.

18 Imam al-Mawardi, Al-Ahkam As-Sultaniyyah: Hukum-hukum Penyelenggaraan Negara dalam Syariat Islam, (Jakarta: Darul Falah, 2006), 3.
} 
laki. Berdasarkan pada al-Qur'an perempuan dengan bebas memasuki semua sektor publik. Perempuan diberi kesempatan untuk berekspresi, baik untuk berargumentasi maupun berbicara di ruang publik, dari yang menjadi mediator konflik, memberikan perlindungan dan suaka politik, melakukan baiat sampai berjihad. ${ }^{19}$

Mengenai peranan perempuan dalam ranah publik ini telah banyak digambarkan pada masa Rasul. Di mana pada masa beliau telah banyak perempuan yang aktif, yang memiliki kompetensi intelektual dan prestasi sosial yang tinggi. Dalam Islam, perempuan dibenarkan aktif dalam berbagai bidang di dalam maupun di luar rumahnya secara mandiri, bersama orang lain, atau dengan lembaga pemerintah maupun swasta, selama pekerjaan tersebut dilakukan dalam suasana terhormat, sopan serta mereka dapat memelihara agamanya dan dapat pula menghindarkan dampak-dampak negatif bagi dirinya dan lingkungannya. Al-Qur'an pun telah memberikan jaminan kepada perempuan untuk bebas memasuki semua bidang kehidupan masyarakat, termasuk politik, ekonomi dan sektor publik lainnya. ${ }^{20}$ Dengan adanya jaminan-jaminan tersebut menunjukkan bahwasanya Islam tidak hanya membatasi ruang gerak perempuan di sektor domestik rumah tangga tangga saja melainkan perempuan juga diberi kebebasan untuk aktif dalam semua sektor publik. Islam telah menempatkan posisi perempuan setara dengan kaum laki-laki serta tidak mentolelir adanya perbedaan dan perlakuan yang tidak adil antara umat manusia.

Perempuan sebagai bagian dari elmen masyarakat pada dasarnya memiliki hak untuk turut serta mewujudkan kemaslahatan melalui perumusan kebijakan publik di lembaga legislatif. Walaupun di masa lalu keanggotaan lembaga legislatif cenderung didominasi kaum laki-laki. Namun secara pasti tidak

${ }^{19}$ Siti Musdah Mulia, Muslimah Reformis: Perempuan Pembaharu Keagamaan, (Bandung: Mizan, 2005), 44

${ }^{20}$ Lihat dalam QS an-Nahl 16:97, Q.S. at-Taubah 9:71. 
ada ketentuan yang mengharuskan syarat laki-laki sebagai anggota lembaga tersebut. Musthafa as-Siba'i berpendapat bahwa Islam sesungguhnya tidak pernah melarang keikutsertaan perempuan dalam merumuskan kebijakan publik (undangundang). Sebab, pembuatan undang-undang niscaya membutuhkan ilmu pengetahuan yang luas dan Islam memberikan hak yang sama kepada laki-laki dan perempuan untuk mendapatkan ilmu pengetahuan. ${ }^{21}$

Salah satu urgensi keanggotaan perempuan di lembaga legislatif ini adalah untuk mengakomodir beberapa aspek yang berkaitan dengan perempuan. Karena para ulama menyepakati bahwa ada beberapa hal dalam masalah perbuatan hukum (kebijakan publik) yang berkaitan dengan perempuan dan keluarga yang perlu ditanggapi langsung oleh perempuan.22 Oleh karena itu keanggotaan perempuan di legislatif merupakan keniscayaan yang harus diapresiasi dengan baik.

\section{Kuota 30\% Perempuan dalam Kancah Perpolitikan Nasional}

Kata kuota dalam kamus Besar bahasa Indonesia diartikan sebagai jatah (jumlah yang ditentukan) ${ }^{23}$ yakni, jatah yang ditentukan oleh undang-undang mengenai jumlah tertentu untuk menduduki sebuah jabatan politik bagi perempuan. Dengan kuota ini keterwakilan perempuan dalam politik (legislatif) di Indonesia lebih diperhatikan.

Upaya memperkuat posisi perempuan dalam politik di antaranya adalah dengan memperkuat partisipasi peran perempuan dalam politik, dalam konteks ini peran partai politik adalah sangat penting dalam rangka memainkan perannya dalam proses demokratisasi di berbagai institusi politik untuk melibatkan perempuan. Dengan demkian maka secara kualitas keterlibatan

\footnotetext{
${ }^{21}$ Abu Syuqqah, Kebebasan Wanita, jilid 2, (jakarta: Gema Insani Press, 1997), 538.

$22 \mathrm{lbid}, 542$.

${ }^{23}$ Departemen Pendidikan Nasional, Kamus Besar Bahasa Indonesia, (Jakarta: Balai Pustaka, $2001), 615$
} 
perempuan dalam dunia politik harus diikuti dengan affirmative action artinya, harus ada kuota yang mengharuskan perempuan dilibatkan dalam aktivitas politik, baik di partai maupun di pemerintahan. ${ }^{24}$

Upaya maksimal pemberdayaan perempuan semacam ini menunjukkan adanya political will dari pemerintah yang apresiatif terhadap perkembangan pengarustamaan gender dalam pergulatan politik nasional. ${ }^{25}$ Yang kemudian dalam upaya lebih lanjut dibuktikan dengan adanya Pasal 55 Undang-Undang No. 8 Tahun 2013 yang berisikan bahwa daftar bakal calon memuat paling sedikit 30\% keterwakilan perempuan.

Jaminan keterwakilan perempuan telah memiliki dasar konstitusional yang kuat. Dalam pasal 28 huruf $\mathrm{H}$ ayat 2 Amandemen Undang-Undang Dasar 1945 menyebutkan bahwa, setiap orang berhak mendapatkan kemudahan dan perlakuan khusus untuk memperoleh kesempatan dan manfaat yang sama dalam mencapai persamaan dan keadilan. ${ }^{26}$

Jaminan keterwakilan perempuan juga diatur dalam beberapa ketentuan hukum, ${ }^{27}$ seperti:

1. Undang-Undang Nomor 7 Tahun 1965 tentang Ratifikasi Konvensi Hak Politik Perempuan.

2. Undang-Undang Nomor 7 Tahun 1984 tentang Pengesahan Konfensi Penghapusan segala bentuk diskriminasi terhadap perempuan.

3. Undang-undang Nomor 39 Tahun 1999 tentang Hak Asasi Manusia.

4. Tap MPR Nomor VI/MPR/2002 merekomendasikan kepada Presiden untuk membuat kebijakan, peraturan dan program khusus untuk meningkatkan keterwakilan perempuan di

\footnotetext{
${ }^{24}$ Tari Siwi Utami, Perempuan Politik di Parlemen, (Jakarta: Balai Pustaka, 200 I), xi.

${ }^{25}$ Ibid, 3-4.

${ }^{26}$ Ida Budhiarti, Strategi Meningkatkan Keterwakilan Perempuan di Lembaga Legislatif dalam pemilu, Semarang 8 Agustus 2003.

${ }^{27}$ Ibid.
} 
lembaga-lembaga pengambil keputsan dengan jumlah minimal $30 \%$.

Dengan landasan yuridis konstitusional di atas maka tidak ada alasan untuk tidak memberlakukan tindakan khusus dalam rangka meningkatkan keterwakilan perempuan di lembagalembaga pengambil kebijakan seperti legislatif. Langkah-langkah kongkrit yang telah dilakukan Indonesia dalam rangka upaya peningkatan keterwakilan perempuan di politik adalah diundangkannya Undang-Undang Pemilu Nomor 8 Tahun 2012 yang dalam pasal 55 memuat tentang ketentuan kuota 30\% bagi perempuan, dan adanya peraturan KPU No. 7 Tahun 2013 yang memberikan sanksi apabila partai politik peserta pemilu tidak bisa mememenuhi kuota 30\%. Undang-undang dan PKPU ini seolaholah mampu menjawab masalah keterwakilan perempuan di bidang politik yang selama ini dianggap masih sangat jauh dari representatif, dan memang undang-undang ini sengaja dibentuk agar kepentingan politik perempuan lebih dapat terakomodir.

Konsep Keterwakilan Calon Legislatif Perempuan Menurut UU No. 8 Tahun 2012

Di dalam Undang-Undang No. 8 tahun 2012 tentang pemilu, terdapat enam pasal yang mengatur mengenai 30\% keterwakilan perempuan dalam pemilu. Pasal-pasal tersebut adalah:

1) Pasal 8 ayat (2)

Partai politik dapat menjadi peserta pemilu setelah memenuhi persyaratan (e) menyertakan sekurang-kurangnya 30\% keterwakilan perempuan pada kepengurusan partai politik tingkat pusat

2) Pasal 15

Dokumen persyaratan sebagaimana yang dimaksud dalam pasal 14 (3) meliputi: (d) surat keterangan dari pengurus pusat partai politik tentang penyertaan keterwakilan perempuan sekurang-kurangnya $30 \%$ sesuai dengan ketentuan peraturan perundang-undangan. 
3) Pasal 55

Daftar bakal calon sebagaimana dimaksud dalam pasal 53 memuat paling sedikit 30\% keterwakilan perempuan.

4) Pasal 56 ayat (2)

Di dalam daftar bakal calon sebagaimana dimaksud pada ayat (1), setiap 3 orang bakal calon terdapat sekurang-kurangnya 1 orang perempuan bakal calon

5) Pasal 58 ayat (3)

KPU Kabupaten/Kota melakukan verifikasi terhadap kelengkapan dan kebenaran dokumen persyaratan administrasi bakal calon anggota DPRD Kabupaten/Kota dan Verifikasi terhadap terpenuhinya jumlah bakal calon sekurang-kurangnya 30\% keterwakilan perempuan.

6) Pasal 59 ayat (2)

Dalam hal daftar bakal calon tidak memuat sekurangkurangnya 30\% keterwakilan perempuan, maka KPU, KPU provinsi dan KPU Kabupaten/Kota memberikan kesempatan kepada partai politik untuk memperbaiki daftar bakal calon tersebut.

Dari isi atau muatan pasal di atas sudah jelas bahwa perempuan mempunyai jatah dalam pemilihan umum atau parlemen sebesar 30\% dan masing-masing ditempatkan di Dewan Perwakilan Rakyat (DPR), Dewan Perwakilan Rakyat Daerah (DPRD) Provinsi, dan DPRD Kabupaten/Kota. Ini juga dapat dilihat sebagai perwujudan dari sistem demokrasi. Di dalam penjelasan pasal di atas juga dinyatakan "cukup jelas" yang artinya angka 30\% ini mutlak bagi perempuan.

Tujuan dari adanya pasal ini tentu saja agar perempuan juga diakui keberadaannya dalam mengurus dan membentuk peraturan perundang-undanganan bagi negara. Artinya perempuan dewasa ini turut serta dalam mensejahterakan masyarakat. Selain itu dengan adanya emansipasi perempuan, pasal ini mencegah adanya sikap diskriminatif terhadap keikutsertaan perempuan dalam berpolitik. 


\section{Peraturan Komisi Pemilihan Umum No. 7 tahun 2013}

Bebeapa pasal yang mendukung adanya affirmative action dalam PKPU No 7 tahun 2013 yaitu:

1) Pasal 11 ayat (a): daftar bakal calon banyak 100\% (seratus persen) dari jumlah kursi yang ditetapkan pada setiap daerah pemilihan

Ayat (b): daftar bakal calon menyertakan sekurang-kurangnya $30 \%$ (tiga puluh persen) keterwakilan perempuan di setiap daerah pemilihan

Ayat (e): nama-nama calon dalam daftar bakal calon disusun berdasarkan nomer urut

Ayat (d): urutan penempatan daftar bakal calon perempuan sebagaimana dimaksud huruf c, yaitu setiap 3 (tiga) orang bakal calon terdapat sekurang-kurangnya 1 (satu) orang perempuan bakal calon.

2) Pasal 24 ayat (1) huruf $c$ dan d : KPU, KPU Provinsi, dan KPU kabupaten/kota melakukan verifikasi selama 14 (empat belas) hari terhadap kelengkapan, kebenaran dan keabsahan persyaratan: (c) Jumlah dan prosentase keterwakilan perempuan paling sedikit $30 \%$ untuk setiap daerah pemilihan sebagaimana dimaksud dalam pasal 11 huruf b. (d) penempatan sekurang-kurangnya satu orang bakal calon perempuan dari setiap orang bakal calon sebagai mana dimaksud dalam pasal 11 huruf $d$.

Ayat (2) dalam hal partai politik telah memenuhi syarat 30\% keterwakilan perempuan dan menempatkan sekurangkurangnya 1 nama bakal calon perempuan pada nomer urut yang lebih kecil, partai poitik dinyatakan telah memenuhi syarat sebagaimana dimaksud pada ayat (1) huruf $d$.

3) Pasal 27 ayat (2) huruf b: parpol tidak memenuhi syarat pengajuan daftar bakal calon pada suatu daerah pemilihan apabila tidak memenuhi syarat sebagaimana pasal 24 ayat (1) huruf $d$ dan ayat (2). 
4) Pasal 50 ayat (2): jumlah minimum penyertaan keterwakilan $30 \%$ perempuan berdasarkan alokasi kursi pada setiap daerah pemilihan anggota DPR, DPRD provinsi dan DPRD Kabupaten/Kota serta penempatannya sebagaimana dimaksud dalam pasal 11 huruf $b$, terlampir dalam lampiran II peraturan ini, dan merupakan bagian yang tidak terpisahkan dari peraturan ini.

Penguatan kebijakan afirmatif melalui Peraturan KPU sangat strategis karena berkaitan dengan pemenuhan tanggung jawab partai politik peserta pemilu untuk mencalonkan minimal 30\% perempuan sesuai perintah Undang-undang. Peraturan KPU sebagai pelaksana teknis ketentuan UU sangat strategis untuk mengatur bahwa daftar bakal calon pada setiap daerah pemilihan harus memuat paling kurang 30\% perempuan bakal calon. Jika partai politik tidak memenuhi daftar bakal calon sebagaimana diatur maka sesuai dengan Pasal 27 Ayat 2 huruf b PKPU No. 7 Tahun 2013 berarti parpol tidak bisa mengajukan caleg untuk mengikuti pemilu di daerah pemilihan bersangkutan.

\section{Keterwakilan Calon Legislatif Perempuan di Dapil 4 Kabupaten} Gresik dalam Pemilu Tahun 2014

Berdasarkan keputusan Komisi Pemilihan Umum Nomor 107/kpts/KPU/TAHUN 2013 pada tanggal 19 Maret 2013 dapil 4 Kabupaten Gresik meliputi Kecamatan Duduk Sampeyan, Benjeng, Cerme dan Balong Panggang.

Di dapil 4 Gresik terdapat 12 partai politik yang mengikuti pemilu DPRD kabupaten/kota dengan jumlah calon legislatif (caleg) di dapil 4 sebanyak 104 orang, laki-laki sebanyak 68 orang $(56,39 \%)$ dan perempuan sebanyak 36 orang $(34,61 \%)$. Tercatat jumlah pemilih sebanyak 46.967 orang di Kecamatan Duduk Sampeyan, 57.950 orang di Kecamatan Benjeng, 69.228 orang di Kecamatan Cerme, dan 52.014 orang di Kecamatan Balong Panggang. 
Tabel 1

Keterwakilan Caleg Perempuan di Dapil 4 Gresik

\begin{tabular}{|c|l|c|c|c|}
\hline No & \multicolumn{1}{|c|}{ Parpol } & $\begin{array}{c}\text { Jumlah } \\
\text { Caleg }\end{array}$ & $\begin{array}{c}\text { Laki-Laki } \\
\mathbf{( \% )}\end{array}$ & $\begin{array}{c}\text { Perempuan } \\
\mathbf{( \% )}\end{array}$ \\
\hline 1. & NasDem & 10 & $7(70 \%)$ & $3(30 \%)$ \\
\hline 2. & PKB & 10 & $7(70 \%)$ & $3(3 \%)$ \\
\hline 3. & PKS & 10 & $6(60 \%)$ & $4(40 \%)$ \\
\hline 4. & $\begin{array}{l}\text { PDI } \\
\text { Perjuangan }\end{array}$ & 9 & $6(66,67 \%)$ & $3(33,33 \%)$ \\
\hline 5. & GOLKAR & 10 & $7(70 \%)$ & $3(30 \%)$ \\
\hline 6. & GERINDRA & 10 & $7(70 \%)$ & $3(30 \%)$ \\
\hline 7. & DEMOKRAT & 9 & $6(66,67 \%)$ & $3(33,33 \%)$ \\
\hline 8. & PAN & 9 & $6(66,67 \%)$ & $3(33,33 \%)$ \\
\hline 9. & PPP & 10 & $6(60 \%)$ & $4(40 \%)$ \\
\hline 10. & HANURA & 8 & $5(62 \%)$ & $3(38 \%)$ \\
\hline 11. & PBB & 5 & $3(60 \%)$ & $2(40 \%)$ \\
\hline 11. & PKPI & 4 & $2(50 \%)$ & $2(50 \%)$ \\
\hline \multicolumn{2}{|l|}{ Jumlah } & $\mathbf{1 0 4}$ & $\mathbf{6 8}$ & $\mathbf{3 6}(\mathbf{3 4}, \mathbf{6 1} \%)$ \\
\hline
\end{tabular}

Sumber: Berita Acara Laporan Penyelenggaraan Pemilihan Umum Tahun 2014 Untuk Dapil 4 Kabupaten Gresik Oleh Komisi Pemilihan Umum Kabupaten Gresik

Dari 12 partai politik kontestan Pemilu tahun 2014 di dapil 4 Kabupaten Gresik, hanya ada 7 partai politik yang berhasi memperoleh sejumlah kursi di dewan. Ke 7 partai politik tersebut adalah:

Tabel 2

Partai Politik yang Memperoleh Kursi DPRD Gresik Dapil 4

\begin{tabular}{|l|l|c|c|c|}
\hline No & $\begin{array}{l}\text { Partai } \\
\text { Politik }\end{array}$ & $\begin{array}{c}\text { Jumlah } \\
\text { Dewan }\end{array}$ & Laki-Laki & Perempuan \\
\hline 1. & Nasdem & 1 & 1 & - \\
\hline 2. & PKB & 1 & 1 & - \\
\hline
\end{tabular}




\begin{tabular}{|l|l|c|c|c|}
\hline 3. & $\begin{array}{l}\text { PDI } \\
\text { Perjuangan }\end{array}$ & 1 & 1 & - \\
\hline 4. & GOLKAR & 3 & 2 & 1 \\
\hline 5. & GERINDRA & 2 & 2 & 1 \\
\hline 6. & PAN & 1 & 1 & - \\
\hline 7. & PPP & 1 & 1 & - \\
\hline \multicolumn{2}{|l|}{ Jumlah } & $\mathbf{1 0}$ & $\mathbf{8}$ & $\mathbf{2}$ \\
\hline
\end{tabular}

Sumber: Berita Acara Laporan Penyelenggaraan Pemilihan Umum Tahun 2014 Untuk Dapil 4 Kabupaten Gresik Oleh Komisi Pemilihan Umum Kabupaten Gresik

Dengan melihat data di atas, dari 104 calon legislatif, yang menjadi anggota dewan hanya 10 orang di lembaga legislatif (DPRD Kabupaten/Kota Gresik) yang mewakili dapil 4 Kabupaten Gresik untuk priode 2014/2019, laki-laki memperoleh kursi sebanyak 8 orang $(80 \%)$ dan perempuan sebanyak 2 orang $(20 \%)$ kursi.

Implementasi Kuota $30 \%$ Keterwakilan Calon Legislatif Perempuan Didapil 4 Kabupaten Gresik Menurut Prespektif Fiqh Siyasah

Dalam catatan historis pada masa awal Islam menunjukkan bahwasanya banyak perempuan terjun dalam sektor publik, seperti Ummu Salamah (istri Nabi Muhammad saw.), Shafiyah, Ummu Sinam al-Aslamiyah. Hal ini menunjukkan bahwasanya Islam mengakui peranan penting yang diemban perempuan dalam bidang publik, karena perempuan mempunyai hak dan kewajiban yang sama, seperti yang dikemukakan oleh Mahmud Syaltut mantan Syaikh al-Azhar, yaitu sebagai berikut:

Tabiat kemanusiaan antara laki-laki dan permpuan hampir dapat (dikatakan) sama. Allah telah menganugerahi kepada perempuan sebagaimana menganugerahkan kepada laki-laki, kepada mereka berdua dianugerahkan Tuhan potensi dan kemampuan yang cukup untuk memikul tanggung jawab dan 
yang menjadikan kedua jenis kelamin ini dapat melaksanakan aktivitas-aktivitas yang bersifat umum maupun khusus. ${ }^{28}$

Dalam Islam, perempuan dibenarkan aktif dalam berbagai bidang di dalam maupun di luar rumahnya secara mandiri, bersama orang lain, atau dengan lembaga pemerintah maupun swasta, selama pekerjaan tersebut dilakukan dalam suasana terhormat, sopan serta mereka dapat memelihara agamanya dan dapat pula menghindarkan dampak-dampak negatif bagi dirinya dan lingkungannya. Al-Qur'an pun telah memberikan jaminan kepada perempuan untuk bebas memasuki semua bidang kehidupan masyarakat, termasuk politik, ekonomi dan sektor publik lainnya. ${ }^{29}$

Dua tugas berupa pembuatan perundang-undangan dan pengawasan atas wewenang eksekutif, merupakan tugas "umat khusus" yang diwajibkan oleh Allah atas umat umum baik lakilaki maupun perempuan untuk membentuknya. Allah SWT berfirman: Surat at-Taubah ayat 71 yang artinya:

“Dan orang-orang yang beriman, lelaki dan perempuan, sebahagian mereka (adalah) menjadi penolong bagi sebahagian yang lain. mereka menyuruh (mengerjakan) yang ma'ruf, mencegah dari yang munkar, mendirikan shalat, menunaikan zakat dan mereka taat pada Allah dan Rasul-Nya. Mereka itu akan diberi rahmat oleh Allah; Sesungguhnya Allah Maha Perkasa lagi Maha Bijaksana." 30

Islam mengakui kesetaraan antara laki-laki dan perempuan dalam berbagai hal termasuk dalam kancah perpolitikan, akan tetapi dalam perspektif Islam, tidak ditemui satupun pembahasan mengenai penerapan kuota 30\% keterwakilan perempuan di parlemen. Perdebatan menganai masalah kuota 30\% keterwakilan perempuan di parlemen merupakan pembahasan kekinian yang

\footnotetext{
${ }^{28}$ Lily Zakiyah Munir, Memposisikan Kodrat Perempuan dan Perubahan dalam Prespektif Islam, (Bandung: Mizan, 1999), 80.

29 Lihat dalam QS an-Nahl 16:97, Q.S. at-Taubah 9:7I.

${ }^{30}$ Departemen Agama RI, Al-Qur'an dan Terjemahnya, 266.
} 
kemudian dijadikan UU dalam rangka pengakuan dan kesetaraan gender di Indonesia. Menurut perspektif fiqh siyasah, keterwakilan $30 \%$ kuota perempuan di parlemen tidak bertentangan dengan prinsip Islam selama perempuan yang duduk di parlemen tersebut mempunyai kapasitas dan kapabilitas sebagai seorang pemimpin, karena Islam menganut prinsip kesetaraan hak antara laki-laki dan perempuan.

Jika pada masa lalu perempuan tidak menggunakan hak ini bukan berarti perempuan tidak boleh dan tidak mampu, tetapi karena tidak ada kebutuhan yang mendesak untuk mempraktikkannya. Ini bukan berarti hak politik perempuan tidak diakui, justru menjadi hak yang dituntut dan dianggap sangat urgen, terutama pada saat sekarang ini.

\section{Penutup}

Implementasi kuota 30\% keterwakilan calon anggota legislatif perempuan di dapil 4 Gresik sudah sesuai dengan UU No. 8 tahun 2012 dan Peraturan KPU No 7 tahun 2013. Tercatat calon anggota legislatif dalam DCT (Daftar Calon tetap) yakni terdapat 34,61\% atau sebanya 36 orang keterwakilan calon legislatif perempuan dari 104 keseluruhan jumlah calon legislatif di dapil 4. Akan tetapi dalam hasil akhirnya 34,61\% keterwakilan perempuan calon anggota legislatif tidak memenuhi kuota $30 \%$, bahkan cuma ada 2 orang (20\%) dari 10 orang anggota dewan yang mewakili dapil 4 Kabupaten Gresik. Ini dikarenakan beberapa faktor yaitu: a) Sistem pemilu yang rumit b) Faktor ekonomi perempuan yang rendah. c) Kondisi sosial budaya dan keagamaan masyarakat yang patriarki. d. Tidak adanya legislasi undang-undang yang menetukan caleg jadi perempuan.

Memberikan peluang terhadap perempuan untuk menduduki jabatan politik baik di legislatif, eksekutif, maupun yudikatif itu tidak berarti menyalahi syari'at, menurut prinsip Islam, perempuan diperbolehkan melakukan peran-peran tersebut dengan konsekwensi bahwa ia dapat dipandang mampu dan 
memiliki kapasitas untuk menduduki peran sosial dan politik tersebut. Dengan kata lain bahwa kedudukan perempuan dalam proses sistem negara-bangsa telah terbuka lebar terutama perannya dalam masyarakat majmuk ini, dengan tetap mengingat bahwa kualitas, kapasitas, kapabilitas dan akseptabilitas bagaimanapun harus menjadi ukuran sekaligus tanpa melupakan fungsi kodrati perempuan sebagai sebuah keniscayaan.

\section{Daftar Pustaka}

Departemen Agama RI. Al-Qur'an dan Terjemahnya. Semarang: Asy-syifa, 1999.

Departemen Pendidikan Nasional. Kamus Besar Bahasa Indonesia. Jakarta: Balai Pustaka, 2001.

Esposito, John L. Islam and Development: Religion and Sociopolitical

Change. New York: Syracuse University Press, 1980.

Fudhali, Ahmad. Perempuan Di Lembaan Suci: Kritik Atas HaditsHadits Shahih. Yogyakarta: Pilar Reigia, 2005.

Iqbal, Muhammad. Figh Siyasah Kontekstualisasi Doktrin Politik Islam. Jakarta: Gaya Media Pratama, 2001.

Jung, Mahomed Ullah Ibn S. The Administration of Justice In Islam: An Introduction to The Muslim Conception of The State. New Delhi: Kitab Bhavan, 1990.

Manzur, Muhammad Ibn. Lisan al-'Arab. Jilid I, Beirut: Dar Shadir, t.t.

Mawardi (al-), Imam. Al-Ahkam As-Sultaniyyah: Hukum-hukum Penyelenggaraan Negara dalam Syariat Islam. Jakarta: Darul Falah, 2006.

Mulia, Siti Musdah. Muslimah Reformis: Perempuan Pembaharu Keagamaan. Bandung: Mizan, 2005.

Munir, Lily Zakiyah. Memposisikan Kodrat Perempuan dan Perubahan dalam Prespektif Islam. Bandung: Mizan, 1999.

Shihab, M. Quraisy. Membumikan Al-Qur'an: Fungsi dan Peran Wahyu dalam Kehidupan Masyarakat. Bandung: Mizan, 1994. 
Surbakti, Ramlan; Didik Suprianto dan Hasyim Asyari. Meningkatkan Keterwakilan Perempuan: Penguatan Kebijakan Afirmasi. Jakarta: Kemitraan Pembaruan bagi Tata Pemerintah, 2009.

Syuqqah, Abu. Kebebasan Wanita. Jilid 2, Jakarta: Gema Insani Press, 1997.

Umar, Nasaruddin. Argumen Kesetaraan Gender Prespektif al-Qur'an. Jakarta: Paramadina, 1999.

Utami, Tari Siwi. Perempuan Politik di Parlemen. Jakarta: Balai Pustaka, 2001.

Zaini, A. Wahid, dkk. Memposisikan Kodrat. Bandung: Mizan, 1999. http://id,wikipedia.org/wiki/Kebijakan_Publik, diakses pada 01 Juni 2014. 